ISSN 1991-8631

Original Paper

http://indexmedicus.afro.who.int

\title{
Oxidative damage on the testes of adult rats by sodium metabisulfite (MBS)
}

\author{
Olusegun Lateef ADEBAYO ${ }^{1 *}$ and Gbenga Adebola ADENUGA ${ }^{2}$ \\ ${ }^{l}$ Department of Chemical Sciences College of Natural Sciences, Redeemer's University, \\ Km46 Lagos/Ibadan Expressway, Redemption City, Mowe,Ogun State, Nigeria. \\ ${ }^{2}$ Department of Biochemistry Faculty of Basic Medical Sciences, Olabisi Onabanjo University P.M.B 2005, \\ Remo Campus, Ikenne, Ogun State, Nigeria. \\ *Corresponding Author; Tel: +2348032320195, +2348055154373; E-mail: spadebayo@yahoo.com
}

\begin{abstract}
The effect of sodium metabisulfite (MBS, $\mathrm{Na}_{2} \mathrm{~S}_{2} \mathrm{O}_{5}$ ) on the level of malondialdehyde (MDA), testes weight and the activities of antioxidant enzymes such as superoxide dismutase (SOD), catalase (CAT) as well as the level of glutathione (GSH) were investigated in the testes of Wistar albino rats. The study was performed to elucidate the effect of MBS $(520 \mathrm{mg} / \mathrm{kg} /$ day) ingestion on lipid peroxidation and the antioxidant enzymes activities. The results showed that MDA level as well as the activity of SOD was significantly increased in MBS-treated rats whereas the weight of the testes as well as the level of GSH was not significantly affected. However, there was significant reduction in the activity of CAT in the MBS-treated rats compared to the control. The presented data showed that ingestion of MBS has adverse effect on testes as it induced oxidative damage, reflected by increase lipid peroxidation and impairment in the activities of antioxidant enzymes. (C) 2011 International Formulae Group. All rights reserved.
\end{abstract}

Keywords: Sodium metabisulfite, testes, lipid peroxidation, glutathione, catalase, superoxide dismutase

\section{INTRODUCTION}

Sulfite and related chemical such as sulfite salt and sulfur dioxide has been used as preservatives in food and drugs. Considerable amount of sulfites is generated in vivo from the catabolism of sulfur-containing amino acids such as cysteine and methionine (Ozturk et al., 2010; Elmas et al., 2005). Five sulfite salts including sodium metabisulfite $\left(\mathrm{Na}_{2} \mathrm{~S}_{2} \mathrm{O}_{5}\right)$, potassium metabisulfite $\left(\mathrm{K}_{2} \mathrm{~S}_{2} \mathrm{O}_{5}\right)$, sodium sulfite $\left(\mathrm{Na}_{2} \mathrm{SO}_{3}\right)$, sodium bisulfite $\left(\mathrm{NaHSO}_{3}\right)$, potassium sulfite $\left(\mathrm{K}_{2} \mathrm{SO}_{3}\right)$ are commonly used as antioxidants in food preparations (Elmas et al., 2005). In addition to this, studies have postulated that under certain conditions, sodium metabisulfite may act through cell disruption and compromise membrane permeability and lipid peroxidation (Derin et al., 2006).

Sulfite can cause allergic reactions in humans, produces a variety of toxic effects in animals and may act as co-carcinogen (MacPherson, 2001; Gordon et al., 2004; Ercan et al., 2010). In humans, deficiency of sulfite oxidase, an enzyme which catalyses the oxidative detoxification of sulfite, leads to 
mental retardation, neurological symptoms such as spastic quadriplegia and early death (Niknahad and O'Brien, 2008).

Testis is the organ that produces sperm, the male reproductive cell, and androgens, the male hormones. Testis is sensitive to a variety of stressors and exposure to agents that induce germ cell apoptosis (O'Bryan et al., 2000). This organ has fairly high concentrations of antioxidant and the defense against the oxidative stress plays critical roles in the maintenance of spermatogenesis and prevention of testicular atrophy. The present study was aimed at determining the effect of sodium metabisulfite ingestion on antioxidants and lipid peroxidation in the testes of adult rats.

\section{MATERIALS AND METHODS} Animals and chemicals

All reagents were of analytical grade and obtained from sigma chemical Co., USA and BDH chemical Ltd; Poole, England. All experimental protocols conducted on rats were performed in accordance with international standard on animal ethics. Male albino Wistar rats weighing 150-200 $\mathrm{g}$ used for the experiment were obtained from animal house of the University of Ibadan, Ibadan, Nigeria. They were allowed to acclimatize for a period of two weeks and maintained at $12 \mathrm{~h}$ lightdark cycles at room temperature. At the end of two weeks, rats were randomly divided into two groups: A and B with seven (7) rats per group and kept in different wire cages. The two groups fed, ad libitum, on growers mash and water and the weight of rats were taken weekly. At the beginning of second week of the commencement of the experiment, animals in group $\mathrm{B}$ were given 520 $\mathrm{mg} / \mathrm{Kg} /$ day $\mathrm{MBS}\left(\mathrm{Na}_{2} \mathrm{~S}_{2} \mathrm{O}_{5}\right)$ by intragastric intubation for 21 days (Hui et al., 1989). At the end of 21-day treatment period, rats were anaesthetized with diethyl ether and sacrificed. The testes were removed, weighed and kept frozen in the freezer at $-4{ }^{\circ} \mathrm{C}$.

\section{Preparation of testes homogenate}

Two sets of testes homogenates were prepared. $0.5 \mathrm{~g}$ of the testis of individual rat was homogenized in $5 \mathrm{ml} 0.01 \mathrm{M}$ phosphate buffer, pH 7.4 at $4{ }^{\circ} \mathrm{C}$ and kept frozen in the freezer to be used for Catalase, Glutathione and Lipid Peroxidation analyses while another $0.5 \mathrm{~g}$ of the testis was homogenized in $1 \mathrm{ml}$ of isolation buffer (250 mM Sucrose, $5 \mathrm{mM}$ Tris, $1 \mathrm{mM}$ Mercaptoethanol and $0.5 \mathrm{mM}$ Phenylsulphonyl-flouride (PMSF) $\mathrm{pH} 7.4$ at $4^{\circ} \mathrm{C}$ ), also kept frozen in the freezer at $-4{ }^{\circ} \mathrm{C}$ and used for Protein determination and Superoxide dismutase analyses. Each set of the homogenates was centrifuged $(4,000 \mathrm{~g}, 5$ mins, $4{ }^{\circ} \mathrm{C}$ ) and supernatants were stored in the freezer at $-4{ }^{\circ} \mathrm{C}$.

\section{Biochemical analyses \\ Measurement of lipid peroxidation}

Levels of MDA, a product of lipid peroxidation, were measured using the thiobarbituric acid (TBA) according to the method of Vashney and Kale (1990). The method is based on formation of pink colored product (when Malondialdehyde is treated with 2- thiobarbituric acid) which has a maximum absorbance at $531.87 \mathrm{~nm}$.

\section{Assay of glutathione}

Assay for glutathione (GSH) was done by the method of Beutler et al. (1963). This method is based on the development of a stable yellow color when 2-nitrobenzoic acids is added to sulfhydryl compounds. The absorbance was measured at $412 \mathrm{~nm}$ and the value of GSH is proportional to the absorbance at this wavelength.

\section{Catalase assay}

The catalase activity of each testis sample was determined by the method of 
Sinha (1972) but with a slight modification. $0.1 \mathrm{ml}$ of each testis was mixed with $4.9 \mathrm{ml}$ of distilled water. $1 \mathrm{ml}$ of the mixture was added to $\mathrm{H}_{2} \mathrm{O}_{2}$-phosphate buffer mixture. The principle is based on the formation of chromic acetate when hydrogen peroxide $\left(\mathrm{H}_{2} \mathrm{O}_{2}\right)$ reacts with dichromate-glacial acetic acid mixture at $100{ }^{\mathrm{O}} \mathrm{C}$. The decomposition of $\mathrm{H}_{2} \mathrm{O}_{2}$ when acted upon by catalase and reduction of the orange color to a green coloration is measured spectrophotometrically at $570 \mathrm{~nm}$.

\section{Superoxide dismutase (SOD) assay}

Total SOD activity was determined by the method of Del-Maestro et al. (1983). This assay reaction is initiated by adding pyrogallol solution and the change in optical density at $420 \mathrm{~nm}$ is recorded. The principle was based on the ability of SOD to scavenge superoxide anion radical $\left(\mathrm{O}_{2}^{--}\right)$which, by shortening reaction chains, decreases the overall rate of pyrogallol autoxidation.

\section{Protein determination}

In all measurements of antioxidant system and oxidation products, the protein concentrations were evaluated according to Lowry et al. (1951) with bovine serum albumin as standard. The assay measured at
$750 \mathrm{~nm}$ was based on the use of FolinCiocalteau reagent (a solution of phosphomolybdic-tungstic complex) which is reduced by tyrosine residues in protein at alkaline $\mathrm{pH}$ to give blue color.

\section{Statistical analysis}

All values were expressed as mean \pm standard error of mean (SEM), and the data were analyzed using independent $t$ test for significant differences between the two groups. A level of $\mathrm{p}<0.05$ was accepted as statistically significant (SPSS software).

\section{RESULTS}

As shown in the table, there was no significant difference $(\mathrm{P}>0.05)$ in the weight of MBStreated rats when compared with the control. However, result showed that there was a significant increase $(\mathrm{P}<0.05)$ in lipid peroxidation and SOD activity of MBStreated rats and significant decrease $(\mathrm{P}<0.05)$ in catalase activity when compared to appropriate controls. In addition, no significant difference was observed in GSH level of MBS-treated rats when compared with the control.

Table: Effects of sodium metabisulfite (MBS) administration on lipid peroxidation and antioxidant levels in the testes of adult rats.

\begin{tabular}{lccccc}
\hline Treatments & Weight (g) & $\begin{array}{c}\text { Lipid } \\
\text { peroxidation } \\
\text { (MDA) } \mathbf{~ 1 0} \mathbf{1 0}^{\mathbf{4}}\end{array}$ & $\begin{array}{c}\text { Catalase } \\
\text { activity } \\
(\text { Units g }\end{array}$ \\
\end{tabular}




\section{DISCUSSION}

Free radical-induced oxidative damage has been implicated in the pathogenesis of a number of injuries and disease states (Adebayo and Adenuga 2007; Adenuga et al., 2009). The ability of sulfite to cause peroxidation of lipids has been documented in various fatty acid and lipid emulsions (Zaloga and Marik, 2003). Lipid peroxidation is known to have deleterious effects on structure and functions of cell membrane. Considering that unsaturated fatty acids that undergo peroxidation are important constituents of biological membranes, structural and functional deterioration of biological membrane may follow (Meng, 2003). The level of malondialdehyde (MDA) has been shown to be an indicator of endogenous lipid peroxidation (Meng and Bai, 2004). Our result showed that MBS $(520 \mathrm{mg} / \mathrm{kg} /$ day $)$ given by intragastric intubation for 21 days, significantly increased the level of MDA in the testes of adult rats. This result is consistent with other previous reports (Aydin et al., 2005; Derin et al., 2008; Ercan et al., 2010). The mechanisms of sulfite-induced lipid peroxidation have been shown to involve $\mathrm{SO}_{3}{ }^{2-}$ oxidation into a sulfite radical $\left(\mathrm{SO}_{3}{ }^{-}{ }^{-}\right)$. The sulfite radical can subsequently react with molecular oxygen to form sulfite peroxy radical $\left(\mathrm{SO}_{3} \mathrm{OO}\right)$ and a sulfate radical $\left(\mathrm{SO}_{4}^{-}\right)$, which in turn reacts with lipids (Elmas et al., 2005; Ercan et al., 2010). Also, the oneelectron oxidation of bisulphate produces the sulfur trioxide radical anion, which reacts rapidly with molecular oxygen to form peroxyl radical. The free radicals generated can damage nucleic acids and induce mutation (Meng, 2003; Meng and Bai, 2004).

Our result on the weight of testes of MBS-treated rats compared with control was not statistically significant. However, there was reduction in the testes of MBS-treated rats compared with the control. The reduction at the testicular weight could be attributed to the reduced tubule size, spermatogenic arrest and inhibition of steroid biosynthesis of leydig cells (Maneesh et al., 2005). In addition, generation of highly reactive oxygen species (ROS) is another important factor in the damage of this tissue (Adebayo et al., 2011). Oxidative stress in the testes has been reported to be one of the major factors inducing germ cell apoptosis (Maneesh et al., 2005). Our result on lipid peroxidation supports this fact.

In normal condition, cell possesses enzymatic and non enzymatic defenses to cope with free radicals (Adenuga et al., 2008). It has been suggested that many of the clinical and pathological manifestations result from an imbalance between free radical defense system and free radical production. The increase in free radical production has increased the potential for free radicalmediated tissue damage (Ercan et al., 2010).

Superoxide dismutase is a metalloprotein that dismutases $\mathrm{O}_{2}{ }^{-}$to yield hydrogen peroxide $\left(\mathrm{H}_{2} \mathrm{O}_{2}\right)$ and oxygen. At $\mathrm{pH}$ 7.4 , the rate constant for this enzymecatalyzed reaction is $\sim 2 \times 10^{9} \mathrm{M}^{-1} \mathrm{~S}^{-1}$ which is approximately $10^{4}$ times faster than the spontaneous dismutation of $\mathrm{O}_{2}{ }^{--}$(Elmas et al., 2005). The result of the present study showed that there was significant increase in the activity of SOD of MBS-treated rats when compared to the control. The result of this study is at variance with the report of Meng and Bai (2004) who reported that exposure to sulfur dioxide decreased the activity of SOD as well as increased the catalase activity on the testicle of mice. The variations in the activities of these antioxidants might be due to the sources of sulfites, the species of animal used and the routes of administration. The increase activity of SOD in the dismutation of superoxide radicals is expected to result in 
increase hydrogen peroxide generation. SOD is considered as the first line of defense against oxygen toxicity (Meng and Zhan, 2001; Meng and Zhang, 2003). SOD spontaneously dismutases $\mathrm{O}_{2}^{--}$to form (oxygen) $\mathrm{O}_{2}$ and $\mathrm{H}_{2} \mathrm{O}_{2}$. Thus, SOD protects testes against spontaneous $\mathrm{O}_{2}$ toxicity and lipid peroxidation. The $\mathrm{H}_{2} \mathrm{O}_{2}$ formed from SOD and following divalent reduction of oxygen is removed by either glutathione peroxidase $(\mathrm{GPx})$ which catalyses the reduction of $\mathrm{H}_{2} \mathrm{O}_{2}$ by reduced glutathione (GSH) (Elmas et al., 2005) or catalase, another primary scavengers of hydrogen peroxide (Laggner et al., 2005), which cannot be saturated by $\mathrm{H}_{2} \mathrm{O}_{2}$ at any concentration. SOD and CAT also remove $\left(\mathrm{O}_{2}{ }^{\circ}\right)$ generated by NADPH oxidase in neutrophilis and may play an important role in decreasing lipid peroxidation (Maneesh et al., 2005). Our result showing reduction in the activity of catalase suggests that there was repression of CAT activity and that CAT was not able to remove the hydrogen peroxide released by the action of SOD leading to intracellular increase of hydrogen peroxide.

GSH is a major non protein thiol in living organisms which plays a central role in coordinating the body's antioxidant defense processes. Conditions that perturb intracellular levels of glutathione have been shown to result in significant alteration in cellular metabolism. The tissue glutathione concentration reflects its potential for detoxification and it is critical in preserving the proper cellular redox balance and for its role as a cellular protectant (Mari et al., 2001). It is a cofactor for GPx, which catalyses the reduction of hydrogen peroxide to water, thereby limiting the formation of hydroxyl radical, the most toxic of the oxygen-based radicals (Meng and Bai, 2004). As shown in the table, no significant difference was observed in the GSH level in the testes of MBS-treated rats compared to the control. It is well known that the concentration of glutathione in the tissue is a reflection of its potential for detoxification. Thus, it seems that GSH did not play a significant role in scavenging free radicals generated during MBS-induced lipid peroxidation. From the present study, it can be concluded that ingestion of sodium metabisulfite (MBS, $\mathrm{Na}_{2} \mathrm{~S}_{2} \mathrm{O}_{5}$ ) has an adverse effect on testes as it induced oxidative damage, reflected by increase lipid peroxidation which was accompanied by changes in antioxidant status in this organ. It is recommended that further work be done to understand the effect of MBS on sperm and male hormones production.

\section{ACKNOWLEDGMENTS}

We acknowledged Dr. E.O. Okegbile for the procurement of chemicals and Messrs Osineye and Osifeso for technical assistance.

\section{REFERENCES}

Adebayo OL, Adenuga GA. 2007. Protective effect of Selenium on proteinundernutrition induced brain damage in rats. Biol. Trace Elem. Res., 116: 227234.

Adebayo OL, Shallie PD, Adenuga GA. 2011. Lipid peroxidation and antioxidant status of the cerebrum, cerebellum and brain stem following dietary monosodium glutamate administration in mice. Asian J. Clin. Nutr., 3(2): 71-77.

Adenuga GA, Adebayo OL, Adegbesan B. 2008. The response of liver lipid peroxidative and antioxidant defense systems of protein undernourished rats to liver regeneration. Indian J. Clin. Biochem., 23(1): 29-32.

Adenuga GA, Adegbesan BO, Adebayo OL. 2009. Antioxidant defense of Zinc acetate 
supplementation on the brain of proteinundernourished rats. Int. J. Biol. Chem. Sci., 3(1):152-155.

Aydin S, Yargicoglu P, Derin N. 2005. The effect of chronic restraint stress and sulfite on visual evoked potential (VEPs): relation to lipid peroxidation. Food Chem. Toxicol., 43(7): 1093-1101.

Beutler E, Duron D, Kelly BM. 1963. Improved method for the determination of blood glutathione J. Lab. Clin. Med., 61: $882-888$

Del-Maestro RF, McDonald W, Anderson R. 1983. Superoxide Dismutase, Catalase and Glutathione Peroxidase. In Experimental and Human Brain Tumours: Oxy Radicals and Their Scavenger Systems (Vol. 2), Greenwald R, Cohen G (eds). Elsevier Publisher: New York, 16-34.

Derin N, Yargicoglu P, Aslan M, Elmas O, Agar A, Aiciguzel Y. 2006. The effect of sulfite and chronic restraint stress on the brain lipid peroxidation and antioxidant enzyme activities. Toxicol. Ind. Health, 22(6): 233-240.

Derin N, Akpinar D, Yargicoglu P. 2008. Effect of alpha-lipoic acid on visual evoked potentials in rats exposed to sulfite. Neurotoxicol. Teratol., 31(1): 4-9.

Elmas O, Aslan M, caglar S, Derin N, Agar A, Aliciguzel Y, Yargicoglu P. 2005. The prooxidant effect of sodium metabisulfite in rat liver and kidney. Regul. Toxicol. Pharmacol., 42: 77-82.

Ercan S, Ozturk N, Celik-Ozenci C, Gungor NE, Yargicoglu P. 2010. Sodium metabisulfite induces lipid peroxidation and apoptosis in rats gastric tissue. Toxicol. Ind. Health, 26(7): 425-431.

Gordon EM, Myers C, Blumer J. 2004. In vitro evaluation of the potential role of sulfite radical in morphine associated histamine release. BMC Pharmacol., 6: 421.

Hui JY, Beery JT, Higley NA, Taylor SL. 1989. Comparative subchronic oral toxicity of sulphite and acetaldehyde hydroxysulphonate in rats. Food Toxicol., 27: 349-359.

Laggner H, Hermann M, Sturm B, Gmeiner BMK, Kapiotis S. 2005. Sulfite facilitates LDL lipid oxidation by transition metal ions: A pro-oxidant in wine? FEBS Lett., 579: 6486-6492.

MacPherson RD. 2001. Pharmaceutics for the anaesthetist. Anaestthesia 56: 965-979.

Maneesh M, Jayalekshmi H, Sanjiba D, Chakrabarti A, Vasudevan DM. 2005. Role of oxidative stress in ehanol induced germ cell apoptosis- an experimental study in rats. Indian J. Clin. Biochem., 20(2): 62-67.

Mari M, Wu D, Nieto N, Cederbaum AI. 2001. CYP2E1-Dependent toxicity and upregulation of antioxidant genes. $J$. Biomed. Sci., 8(1): 52-55.

Meng Z. 2003. Oxidative damage of sulfur dioxide on various organs of mice: sulfur dioxide is a systemic oxidative damage agent. Inhal. Toxicol., 15: 181-195.

Meng Z, Bai W. 2004. Oxidative damage of sulfur dioxide on testicles of mice. Environ. Res., 96: 298-304.

Meng Z, Zhang B. 2001. Oxidative damage of sulfur dioxide inhalation on brains of rats. Chin. Environ. Sci., 21: 464-467.

Meng Z, Zhang B. 2003. Oxidation damage of sulfur dioxide inhalation on brains and livers of mice. Environ. Toxicol. Pharmacol., 21: 464-467.

Niknahad H, O'Brien PJ. 2008. Mechanism of sulfite cytotoxicity in isolated rat hepatocytes. Chem. Bio. Int., 174: 147154. 
O’Bryan MK, Schlatt S, Philips DJ, de Krester DM, Hedger MP. 2000 Bacterial lipopolysacharide-induced inflammation compromises testicular function at multiple levels in vivo. Endocrinol., 141: 238-246.

Ozturk OH, Oktar S, Aydin M, Kucukatay, V. 2010. Effect of sulfite on antioxidant enzymes and lipid peroxidation in normal and oxidase-deficient rat erythrocytes. $J$. Physiol. Biochem., 66(3): 205-212.
Sinha KA. 1972. Colorimetric assay of catalase. Anal Biochem., 47: 389-394.

Vashney R, Kale RF. 1990. Effect of calmodulin antagonists on radiation induced lipid peroxidation in microsomes. Int. J. Rad. Biol., 58: 733743.

Zaloga GP, Marik P. 2003. Sulfite-induced propofol oxidation: a cause for radical concern. Crit Care Med., 31(3): 787-792. 